\title{
The Long Term Effects of Legalizing Divorce on Children
}

\author{
Libertad González \\ (Universitat Pompeu Fabra) \\ Tarja Viitanen \\ (University of Sheffield)
}

October 2008

\begin{abstract}
We estimate the effect of divorce legalization on the long-term well-being of children. Our identification strategy relies on exploiting the different timing of divorce legalization across European countries. Using European Community Household Panel data, we compare the adult outcomes of cohorts who were raised in an environment where divorce was banned with cohorts raised after divorce was legalized in the same country. We also have "control" countries where all cohorts were exposed (or not exposed) to divorce as children, thus leading to a difference-in-differences approach. We find that women who grew up under legal divorce have lower earnings and income as well as worse health as adults compared with women who grew up under illegal divorce. These effects are not found for men. We find no effects of divorce legalization on children's family formation or dissolution patterns.
\end{abstract}

JEL Codes: J12, J13, K36

Keywords: divorce, legislation, intergenerational effects, child outcomes. 


\section{Introduction}

The legal regulation of divorce has been shown to affect a number of individual and household outcomes, particularly for married adults. ${ }^{1}$ It is plausible to think that divorce laws may also affect child outcomes. We study the effect of legalizing divorce on the long-term well-being of children by exploiting the recent legalization of divorce in several European countries.

A recent literature has studied the effect of unilateral divorce legislation in the US on a variety of outcomes, from divorce rates to spousal well-being, labor supply, withinhousehold bargaining power and marital investments. The findings to date suggest that the introduction of unilateral divorce led to an increase in divorce rates (at least in the short term), ${ }^{2}$ an increase in female labor supply, ${ }^{3}$ and a decline in marriage-specific investments. $^{4}$

Less explored has been the effect of divorce legislation on child outcomes. There is of course a large literature spanning various fields that has long tried to disentangle the effects of parental divorce on child well-being. ${ }^{5}$ But if divorce laws affect not only the divorce rate, but also the economic behavior of couples who stay married, their impact on children may be more widespread, affecting also children in intact families.

\footnotetext{
${ }^{1}$ See, for instance, Alesina \& Giuliano 2007, Gardner \& Oswald 2006, González \& Özcan 2008, Rasul 2006, Stevenson 2007, 2008, Stevenson \& Wolfers 2006.

${ }^{2}$ Friedberg 1998, Gruber 2004, Wolfers 2006.

${ }^{3}$ Stevenson 2008, Genadek et al. 2007.

${ }^{4}$ Stevenson 2007.

${ }^{5}$ See Amato 2000 and Amato \& Keith 1991 for some recent reviews from the sociological literature, and Manski et al. 1992, Tartari 2005, Lang \& Zagorski 2001, Corak 2001 and Saez de Galdeano \& Vuri 2007 for some recent contributions in economics.
} 
A few recent studies (Johnson \& Mazingo 2000, Gruber 2004, Cáceres-Delpiano \& Giolito 2008) have addressed the effect of unilateral divorce in the US on child outcomes. Their results suggest that unilateral divorce legislation had a negative, long-lasting effect on children's economic well-being. Gruber (2004) finds that exposure to unilateral divorce legislation as a child has a significant negative effect on adult outcomes, such as educational attainment and household income. He also finds that exposure to unilateral divorce during childhood leads to earlier marriages (but more divorces), and lower labor force attachment and earnings for women.

However, recent research suggests that the direct effect of unilateral legislation on divorce rates may have been limited in the long term (Wolfers 2006). Thus, those results are likely to be driven almost exclusively by the "indirect" channels, which cannot be identified separately. Moreover, divorce rates were already high by international standards in the US before the introduction of unilateral divorce, so that the estimated effects would be driven by marginal changes in the divorce rate or the perceived risk of divorce.

At the same time, European countries have in recent decades undergone much broader reforms in their divorce legislation, and some countries have even legalized divorce fairly recently, resulting in significant increases in divorce rates (González \& Viitanen 2008). We thus propose to exploit the recent legalization of divorce in several European countries in the view that it provides a stronger shock than the legal reforms previously exploited in the literature.

Italy, Portugal, Spain and Ireland legalized divorce between 1971 and 1996. As a result, some cohorts of today's adults received no exposure to divorce as children. 
Divorce legalization was followed by a significant and rising increase in the divorce rate in the four "legalizing" countries (see figure 1). Since pre-reform divorce rates were zero by construction, our analysis can be thought of as shedding light on the effects of the "average" divorce, rather than the "marginal" divorce.

Using European Community Household Panel (ECHP) data, we compare the adult outcomes of cohorts who were raised in an environment where divorce was banned with cohorts raised after divorce was legalized in the same country. We also have "control" countries where all cohorts were exposed (or not exposed) to divorce as children, thus leading to a difference-in-differences approach.

We find that girls raised when divorce is legal have lower wages, earnings and income as adults compared with women who grew up under illegal divorce. This is not true for men, who in fact work more and earn no less if exposed to legal divorce as children. We find essentially no significant effects of legalizing divorce on family formation or dissolution, and analyzing health outcomes confirms some asymmetric effects for men and women.

The remainder of the paper is organized as follows. The next section introduces the data and discusses the method of analysis. Section 3 presents the empirical results, while section 4 discusses the robustness of our findings and section 5 concludes.

\section{Data and methodology}

Our main data source is the European Community Household Panel (ECHP). The ECHP is a large-scale comparative longitudinal survey covering the EU-15 during the period 1994-2001. The ECHP was designed to develop comparable social indicators across the 
EU and covers a range of topics such as labor market activity, education, income, health and demographic characteristics at the individual level.

Our empirical strategy is based on comparing a number of outcomes for individuals who grew up when divorce was illegal with those for adults who grew up after divorce was legalized. Thus our main explanatory variable indicates whether or not an individual was "exposed to legal divorce" during childhood.

The main measure of "exposure to legal divorce" is a binary variable that takes value zero if an individual turned 18 before divorce legislation was passed in his or her country of birth and residence, and 1 otherwise. Thus, an adult is defined as "exposed to divorce as a child" if divorce was allowed in his or her country of birth before he or she turned 18. The sample is further restricted to include individuals aged 25 to 55. Furthermore, the sample includes only individuals who reside in their country of birth. ${ }^{6}$

As mentioned, four countries in Europe legalized divorce only recently. Italy legalized divorce in 1971, while divorce was banned in Portugal until 1977, in Spain until 1981, and in Ireland until 1996. Thus, for instance, the "exposure" dummy takes value 1 for all individuals born in Greece in the sample, since divorce legislation was in place in Greece since 1920 (thus all Greeks in the sample are "exposed"). Ireland was the country where divorce was introduced most recently, thus no one in the Irish sample was exposed to divorce as a child. Only individuals who turned 18 after 1996 were exposed to divorce in Ireland, but they would only be 22 in 2001, and thus would be excluded from our sample.

\footnotetext{
${ }^{6}$ Only $2 \%$ of the individuals in the sample reported residing in a country different from their country of birth. The specific country of birth cannot be identified.
} 
The remaining three legalizing countries are intermediate cases, where some individuals in the sample were exposed and others were not. For instance, divorce was introduced in Spain in 1981, thus a child born in 1970 would have been exposed to divorce since the age of 11 , and would be 25 years old in 1995 . On the other hand, a child born in 1964 would not have been exposed to divorce as a child at all (turning 18 the same year the divorce legislation was implemented), and this individual would be 31 years old in 1995. Note that those individuals "exposed" to divorce are younger than those not exposed, thus it will be crucial to control for age effects.

The sample results in the following cohorts that are exposed to legalized divorce:

1. Ireland: None are exposed. Exposed if born after 1978 (15 or younger in 1994, 22 in 2001), i.e. nobody in our sample.

2. Spain: exposed if born after 1964 (in 2001, people aged 25 to 36 are exposed, older than 36 not exposed).

3. Portugal: exposed if born after 1957 (in 2001, people aged 25 to 43 are exposed, older than 43 not exposed).

4. Italy: exposed if born after 1952 (in 2001, people aged 25 to 48 are exposed, older than 48 not exposed).

5. Rest of EU-15: All are exposed (age in 2001: 25 to 55).

To assess the impact of legal divorce as a youth on adult outcomes, we estimate the following regression model:

$$
Y_{i b c t}=\alpha+\beta_{1} \operatorname{EXPOSED}_{b c}+\sum \gamma_{a g e} A G E_{i b c t}+\mu_{c}+\delta_{t}+\varepsilon_{i b c t}
$$

Where subscript $i$ denotes the individual, $b$ proxies year of birth, $c$ denotes the country and $t$ indicates the year when the outcome is observed. Different adult outcomes $(Y)$ are 
estimated to be a function of exposure to divorce as a child (EXPOSED), as well as age, country and year. Age is introduced as a set of dummies to allow for as much flexibility as possible in the age profile. Country and year fixed effects are included.

The regressions are estimated separately for men and women, and additional specifications are estimated including country-specific trends, either in current year $(t)$ or in year of birth $(b)$. These trends are meant to control for country-specific factors that move smoothly over time. We also run regressions where exposure is measured using three separate dummies in order to account for the length of exposure (1 to 4 years, 5 to 8 years, and more than 8 years). The baseline specification follows closely the approach in Gruber (2004). The adult outcomes that we analyze can be grouped in three categories: income and labor market variables, family formation and dissolution variables (marital status and fertility) and health status.

Table 1 summarizes the variables used in the analysis for the four legalizing countries plus Greece as the additional control country. We choose Greece as the main "control" country due to its economic and social similarities with the "treated" countries. Greece is a Southern European country, which entered the European Union recently and followed a similar path in its economic development as Spain or Portugal. It is also a country with low levels and coverage of social assistance, and although divorce has been legal since 1920, divorce rates have remained among the lowest in Europe.

The whole sample is included in the first panel and then separated into sub-samples of "not exposed" and "exposed" to divorce during childhood in the second and third panels, respectively. Sample size is about 240,000 individual observations. Descriptive statistics broken down by gender can be found in the appendix. 
About $54 \%$ of the individuals in the sample were exposed to divorce as children, and average exposure before age 18 is 6 years. Average age is 39 , but the sample of exposed children is significantly younger than the sample not exposed. Thus it will be crucial to account for age in all specifications.

Exposed individuals are more likely to be never married and less likely to be living in a couple, married, separated or divorced than those not exposed, while they are more likely to have children. The exposed sample has lower income and earnings but is more educated. They are also less likely to report bad health. Note that these associations are likely to be related to the different age profiles of the two sub-samples.

\section{Results}

All specifications reported in this section use pooled ECHP data for the period 1994-2001 and are estimated separately for the sample of men and women. The sample includes men or women aged 25 to 55 and born and living in Greece, Ireland, Italy, Portugal or Spain. All models include as controls a set of age dummies ${ }^{7}$ as well as year and country dummies. All standard errors are clustered at the level of birth year interacted with country (the level of aggregation of the main explanatory variable). We report the results for four sets of outcome variables. The first includes a range of labor market and income variables. The second comprises several measures of educational attainment. The third includes some indicators of family formation and dissolution, and the fourth covers a number of measures of health outcomes.

\footnotetext{
${ }^{7}$ We include ten 3-year age dummies.
} 


\subsection{Labor market and income outcomes}

Table 2 presents the results of three specifications for each of the eight income and employment outcome variables, separately for men and women. Each cell reports the coefficient and standard error corresponding to exposure to legal divorce during childhood in the different regressions, ${ }^{8}$ where the dependent variable is a measure of income, employment or earnings (depending on the row). The first column reports the estimates from the basic specification that controls for age, year and country. The country fixed-effects account for unobserved factors at the national level that may affect both the outcome variables and the timing of the divorce legislation, such as, say, the religious heritage in each country. The second column adds country-specific linear trends, in order to control for unobserved variables that may be changing at different paces across countries, such as current economic conditions. Finally, the third column interacts country with linear birth-year trends, to account for cohort effects.

The results in the first panel of table 2 show that men who were exposed to legal divorce during childhood are significantly more likely to currently hold a job by 2 to 4 percentage points (for an average employment rate of $85 \%$ ), and those who are employed work significantly longer hours (.4 to .6 hours more a week, for an average of 45 ). As a result, their monthly earnings are higher, even though their hourly wage is the same. Exposed men are also less likely to be on benefits (by 3 to 6 percentage points). On average, their total income is not significantly different from that of men not exposed. Note that significance levels are slightly lower in the third specification, but typically the sign and magnitude of the effects are unchanged. In sum, we find essentially no effect on

\footnotetext{
${ }^{8}$ All specifications are linear.
} 
wages, earnings or income for men, although we do find some effect on labor supply (exposed men work more).

The second panel of table 2 displays the income and employment results for the sample of women. Adult women who grew up under legal divorce have similar employment levels as those who grew up while divorce was banned. However, they tend to work fewer hours (between .4 and .9 a week, for an average of 37). Consequently, their monthly earnings are significantly lower, by 5 to 11 percent. Moreover, their hourly wage is also significantly lower, by 3 to 5 percent. Exposed women are slightly more likely to be on benefits, but those who are receive significantly lower amounts than their nonexposed counterparts. All of this results in exposed women having significantly lower income, by $27-29 \%$ according to the first two specifications, or $7 \%$ according to the third.

We may expect that, if exposure to divorce during childhood is driving the estimated effects, those effects would be stronger for children exposed during their whole childhood compared with those exposed during a shorter period. The effects may also be different for children exposed since early ages versus those exposed only since their teen years. ${ }^{9}$ Thus we exploit the variation in length of exposure by defining three separate dummies for children exposed during 1 to 4 years, 5 to 8 years, and 9 or more years. ${ }^{10}$

The results for the income and work outcomes by length of exposure are reported in table 3. We report only the preferred specification, which includes country-specific trends by year of birth (as in column 3 in table 2). These results support the findings from the

\footnotetext{
${ }^{9}$ Note that we cannot separate the effect of years of exposure from the effect of age at exposure since they are perfectly correlated. A child exposed to divorce for 10 years will necessarily be exposed since age 7 .

${ }^{10}$ As in Gruber (2004).
} 
previous table. The effect of exposure to legal divorce during childhood on current employment for men increases in size and significance with length of exposure (first panel). Men exposed for up to 4 years are 4 percentage points more likely to be employed compared with non-exposed men, while the effect is 6 points for men exposed for 9 years or more. The effect on hours worked is also increasing in exposure. Note also that the effect on monthly earnings is significantly positive for men exposed during 9 years or more, even though it was not significant on average.

The main results for the sample of women are also reinforced when we allow for the effects to vary with length of exposure (second panel of table 3). Longer exposure to legal divorce during childhood is significantly associated with lower monthly earnings and lower hourly wages. This also leads to a significant negative effect on total income. The magnitude of the estimated effects is large. The income level of women exposed for up to 4 years is 8 percent lower relative to non-exposed women, while the effect increases to 13 percent for women exposed for 5 to 8 years, and reaches 25 percent for those exposed for more than eight years.

Summing up, we find that the effects of legalizing divorce on the long-term labor market outcomes of children are quite different for men and women. Legalizing divorce does not appear to harm wages or income for men, and it appears to lead to higher employment rates and hours worked. However, exposure to legal divorce during childhood leads to lower wages, earnings and income for women. 


\subsection{Educational attainment outcomes}

Table 4 shows the results for several outcome variables related to educational attainment, which may help understand the earnings and employment results. The first two variables are dummies that indicate the completion of a high school degree and a university degree, respectively. The third shows the effects on years of full-time education, and the last refers to the age when the individual first entered the labor market.

The results in the first panel of table 4 show that men exposed to legal divorce as children are slightly less likely to have completed a high school degree (by .5 to 3 percentage points), while there is a small positive (but not significant) effect on college education (of .5 to 2 points) . On average, however, exposed men spent between .3 and .4 more years in full-time education. This is in turn reflected in a later age when entering the labor market (by .4 to .5 years).

The estimated effects on educational outcomes are not very different for women (second panel of table 4). Exposure to legal divorce during childhood has no discernible effect on educational attainment, but exposed women do appear to stay longer in school (by .3 to .4 years) and start working later (about .4 years). Thus, the differential labor market effects shown in tables 2 and 3 do not appear to take place through differential effects on educational attainment. One caveat, however, is the low quality of the education variables available in the ECHP, which only report three levels of education (primary, secondary and tertiary). Perhaps a more detailed education measure would shed more light on the true underlying effects.

The effect on educational attainment is allowed to vary by length of exposure in table 5. The first panel shows the result for men, and suggest that, in fact, exposure to legal 
divorce may have increased the likelihood of obtaining a college degree. Men exposed by more than eight years are 6 percent more likely to hold a university degree than men not exposed, and this effect is highly significant. However, this positive effect on educational attainment is not reflected in higher high school graduation rates. Length of exposure is also positively associated with years of full-time education. Men exposed by eight or more years have on average almost one more year of education than men not exposed.

We find no significant effect on high school or college graduation for women, although exposed women appear to stay in school longer (by .3 to .7 years, depending on length of exposure).

In sum, we find no clear effects of exposure to legal divorce during childhood on educational attainment. If anything, exposed men appear slightly more likely to complete a college degree. We do find that both men and women stay between .3 and .4 years longer in full-time education. This could imply a higher educational attainment, but it could also result from more grade repetition.

\subsection{Family formation and dissolution outcomes}

Table 6 presents the main results for the family-related outcomes. We estimate the effect of exposure to legal divorce during childhood on current marital status, by using as dependent variables a set of binary indicators for being currently never married, married, living in a couple, separated, divorced, or widowed. We also estimate the effect on fertility by constructing an indicator for living with own children under the age of 16 . Other related outcome variables are age at marriage (for the married subsample) and an 
indicator for single parenthood. Table 6 displays the results for a representative subset of these dependent variables.

Exposure to legal divorce during childhood has no discernible effect on marital status for either men or women. Exposed individuals are no more likely to be living in a couple, married, separated or divorced than their non-exposed counterparts. This is in contrast with the results by Gruber (2004), who found that both men and women who were exposed to unilateral divorce as children tended to marry earlier as adults, but also separated more often. Exposed men appear to be slightly more likely to have children, and they marry significantly later, by .7 to .8 years.

Allowing the results to vary by length of exposure (shown in table 7) does not change these conclusions. No significant effects are found for any of the marital status indicators. These results do appear to confirm that exposed men marry later, and suggest that exposed women do, too, at least those exposed for more than four years.

\subsection{Health outcomes}

Finally, tables 8 and 9 show the results of specifications that estimate the effect of exposure to divorce during childhood on a range of health outcomes. Six dependent variables are considered. The first is an indicator of overall self-reported health status, ${ }^{11}$ while the second one is an indicator variable that takes value one if an individual spent at least one night in the hospital over the previous 12 months. The third one indicates whether an individual is or has been a smoker. "Chronic illness" indicates a chronic health problem, illness or disability. "Current health problem" is a dummy that takes

\footnotetext{
11 "Bad health" takes value 1 if the individual reports that his or her health is in general bad or very bad, and zero otherwise (very good, good or fair).
} 
value 1 if a person reports being hampered in their daily activities by a health problem, and "Recent illness" indicates whether the individual reports having had to "cut down" on their usual daily activities during the previous 2 weeks due to illness. Overall, these variables provide a range of measures of current health status.

The first panel of table 8 reports the main results for men. The most striking result shows that men exposed to divorce during childhood are significantly less likely to smoke as adults. The results for the first two variables suggest a positive effect of exposure on health for men. Exposed men are less likely to report bad health and less likely to have stayed at the hospital recently. However, the coefficients turn insignificant and essentially zero once we include the cohort trends in column 3, suggesting those results may just reflect overall improvements in health status.

The corresponding results for women are shown in the second panel of table 8 . The magnitudes of the estimated effects are very small, and we find no significant effects for any of the six outcomes once the cohort trends are included. Thus, we turn to the results by length of exposure, which may uncover any underlying effects too weak to emerge on average.

Table 9 shows (first panel) that the likelihood of hospital stays for men decreases with length of exposure, as well as the likelihood of being a smoker, adding plausibility to the causal interpretation of the results. More interestingly, significant effects emerge for women exposed to legal divorce for more than four and, especially, more than eight years. Women who were younger than 10 years old when divorce was legalized are 2 percentage points more likely to have had a recent hospital stay (for an average of 7\%), compared with women not exposed to legal divorce as children. They are also more 4 
points more likely to suffer from chronic illness, 5 points more likely to have a health problem that hampers their daily activity, and 2 points more likely to have had to cut down on their usual activities because of illness.

These results suggest negative health effects of exposure to divorce during childhood for women, relative to men, consistent with the asymmetric effects on earnings and income, and consistent as well with Gruber's finding that women exposed to unilateral divorce as children were more likely to commit suicide as adults.

\section{Robustness checks}

We estimate a number of additional specifications as robustness checks. A potential concern is that the results could be driven by the choice of the control countries. Thus, we estimate all specifications with different sets of control countries. In some specifications we include France as well as Greece as controls where all individuals were "exposed" to legal divorce during childhood. France legalized divorce in 1884, and divorce rates in recent decades have been comparable to those in the "treatment" countries. We also estimate a set of regressions where all EU-15 countries are included as controls.

Table 10 reports the results of estimating the effect of exposure to divorce during childhood on the main set of labor supply and earnings variables, including different sets of countries. All specifications include age, country and year dummies, as well as country-specific year of birth trends. The first column is the baseline specification (as shown in column 3 of table 2). The second column shows the results when adding France as an additional control country, and column three includes the rest of the EU-15 as well. 
The results seem quite robust to the alternative control groups. In particular, exposed men are still found to work significantly more, while exposed women earn significantly less.

One may also be worried that one of the legalizing countries might be driving the results, so we run an additional set of regressions where we drop each of the five baseline countries (Spain, Italy, Ireland, Portugal and Greece) one at a time. These results are shown in columns 4 to 8 of table 10. Although the magnitudes of some of the coefficients change depending on the subset of countries included, no particular country appears to drive the core of the results.

Table 10 thus shows that the main results are very robust to the inclusion of different subsets of countries. We consistently find that exposure to divorce during childhood significantly increased labor supply for men, raising weekly hours by .4 to .9 , and employment by 4 to 5 points (although the employment effects appear to be driven by Italy). We also find strong support for the result that women exposed to legal divorce as children have significantly lower earnings, by 4 to $7 \%$ ( $2 \%$ if we drop Spain), and their total income is lower by 6 to $12 \%$ (although the effect on income goes away when we drop Spain). We also find consistent evidence suggesting no effect on earnings for men.

There is also somewhat weaker evidence of a negative effect on hours worked for women (-.3 to -.9 a week), a small negative effect on hourly wages for men (of -1 to $-3 \%$ ) and especially women (-2 to $-6 \%)$, a small negative effect on income for men (-3 to $-8 \%)$, and a small positive effect on employment for women (of 2 to 3 points, except when we drop Italy).

As additional robustness checks, we also estimate all specifications with the standard errors clustered at the individual level rather than at the treatment variable level (country 
interacted with year of birth), to account for the fact that the same individual is observed repeatedly across the different waves of the panel. Significance levels change only slightly. We also estimate regressions where age is controlled for with the inclusion of a polynomial (age, age squared and age cubed) instead of a set of dummies. The results are slightly stronger but the conclusions are unaltered.

Additional specifications are also estimated that include a control for current exposure to divorce (in addition to exposure during childhood). However, the only adults not currently exposed to divorce in the sample are those in Ireland in 1994 and 1995 (since divorce was legalized in 1996). This variable is never significant and its inclusion does not significantly alter any of the results.

We did not find other national reforms that were correlated in the timing with the legalization of divorce in our baseline set of countries. In particular, we are not aware of any large reforms going on in Italy, Spain and Portugal in the 1970's that were implemented much earlier in Greece and much later in Ireland.

Finally, we estimate specifications where we include additional controls at the country level. These supplementary explanatory variables include (current) male/female unemployment rates, female employment growth rate, public expenditure on social protection per capita, public expenditure on education, etc. Their inclusion affects some of the coefficients slightly, but the main conclusions remain unchanged. Because of potential endogeneity concerns, we chose as main specifications the ones without these controls. $^{12}$

\footnotetext{
${ }^{12}$ Regression results from all specifications discussed in this section are available from the authors upon request.
} 


\section{Conclusions and discussion}

We estimate the causal effect of legalizing divorce on long-term outcomes for children. Our identification strategy is based on exploiting the different timing of the legalization of divorce across European countries. We compare the adult outcomes of children who grew up before divorce was legalized with those who grew up after legalization in a given country, and do so across a number of countries that vary widely in the timing of legalization.

We find consistent evidence suggesting that the legalization of divorce had negative long-term effects on children, particularly females. Women who grew up after divorce was legalized earn significantly lower wages and have lower incomes compared with women growing up under illegal divorce. They also report significantly more health problems. These negative effects are not found for men.

Our labor market results are in line with Gruber's (Gruber 2004), who finds negative effects of unilateral divorce on employment and earnings for women but positive effects for men. Our health results can also be considered in line with Gruber's finding that adults who were exposed to unilateral divorce as children are more likely to commit suicide as adults, the effect being stronger for women.

We find no effect of exposure to divorce during childhood on family formation or dissolution patterns for either men or women. Thus we cannot confirm the results by Gruber (2004), who finds that exposure to unilateral divorce during childhood resulted in earlier marriages and more separations.

The labor market and health effects that we find may have resulted directly from the increase in divorce rates following the legalization of divorce. A large literature 
documents that parental divorce may have detrimental effects on children, and some studies have found more negative effects for girls (Ellis et al. 2003). A recent study also suggests that parents of girls are more likely to divorce, and mothers of girls are less likely to remarry than mothers of boys (Dahl and Moretti 2004).

However, the effects are likely to be at least in part the result of changes in other household outcomes affected by the introduction of divorce, even in intact families. Recent studies have found that divorce legislation can affect female labor supply (Stevenson 2008, Genadek et al. 2007), bargaining power within the household (Chiappori, Fortin \& Lacroix 2002), marital-specific investments (Stevenson 2007), and household saving (González \& Özcan), among others.

Maternal labor supply has in turn been found to affect short- and medium-term child outcomes (Ruhm 2004, Hill et al. 2005, Berger et al. 2008), and some studies find stronger detrimental effects on girls. Moreover, if legal divorce weakens the bargaining power of the wife, this may also result in lower investment in children, since research has found that resources in the hands of the woman are more likely to benefit children and particularly girls (Duflo 2003). Legalizing divorce may also lead to parents devoting fewer resources to their children because the incentives to invest in marriage-specific capital are lowered (Stevenson 2007) or because of increases in precautionary savings in anticipation of a potential divorce (González and Özcan 2008).

Although banning divorce is to our knowledge not a reform under consideration anywhere, some countries have legalized divorce very recently (such as Chile in 2004), and others are currently considering it (such as Malta). Knowledge of the potential longterm impact of these reforms on children should inform the discussion and potentially 
help prevent some of the detrimental effects. However, more research is still needed to disentangle the channels through which legal divorce can affect the long-term well-being of children. 


\section{References}

Alesina \& Giuliano (2007) "Divorce, Fertility and the Value of Marriage." Unpublished draft, Harvard University.

Amato, P.R. (2000) "The Consequences of Divorce for Adults and Children", Journal of Marriage and the Family, 62: 1269-1287.

Amato, P.R. and Keith, B. (1991) "Parental Divorce and the Well-Being of Children: A Meta Analysis", Psychological Bulletin, 110(1): 24-46.

Berger, L., J. Brooks-Gunn, C. Paxson and J. Waldfogel (2008) "First-year maternal employment and child outcomes: Differences across racial and ethnic groups" Children and Youth Services Review, vol. 30, issue 4: 365-387.

Cáceres-Delpiano, J. and E. Giolito (2008) "How Unilateral Divorce Affects Children" IZA Discussion Paper No. 3342.

Chiappori, P.A., B. Fortin and G. Lacroix (2002) "Marriage Market, Divorce Legislation, and Household Labor Supply." Journal of Political Economy, 110(1):37-72.

Corak, M. (2001) "Death and Divorce: The Long-Term Consequences of Parental Loss on Adolescents", Journal of Labor Economics, 19(3): 682-715.

Dahl, G. and E. Moretti (2004) "The Demand for Sons: Evidence from Divorce, Fertility, and Shotgun Marriage" NBER Working Paper No. 10281.

Duflo, E. (2003) "Grandmothers and Granddaughters: Old-Age Pensions and Intrahousehold Allocation in South Africa." World Bank Economic Review, Vol. 17(1): $1-25$.

Ellis, B., J. Bates, K. Dodge et al. (2003) "Does Father Absence Place Daughters at Special Risk for Early Sexual Activity and Teenage Pregnancy?" Child Development, Vol. 74, No. 3: 801-821.

Friedberg, L. (1998) "Did Unilateral Divorce Raise Divorce Rates? Evidence From Panel Data", American Economic Review, 83(3).

Gardner, J. and Oswald, A.J. (2006) "Do Divorcing Couples Become Happier by Breaking Up?" Journal of the Royal Statistical Society Series A, 169(2): 319-336.

Genadek, Katie R., Wendy A. Stock, and Christiana Stoddard. 2007. "No-Fault Divorce Laws and the Labor Supply of Women with and without Children." Journal of Human Resources 42(1): 247-274.

González, L. and Özcan, B. (2008) "The Risk of Divorce and Household Saving Behavior", IZA Discussion Paper No.? 
Gonzalez, L. and Viitanen, T.K. (2008) "The Effect of Divorce Laws on Divorce Rates in Europe", European Economic Review, forthcoming.

Gruber, J. (2004) "Is Making Divorce Easier Bad for Children? The Long-Run Implications of Unilateral Divorce”, Journal of Labor Economics, 22(4): 799-833.

Hill, J., J. Waldfogel, J. Brooks-Gunn and W.J. Han (2005) "Maternal Employment and Child Development: A Fresh Look Using Newer Methods." Developmental Psychology, Vol. 41, No. 6: 833-850

Johnson, J.H. and Mazingo, C.J. (2000) "The Economic Consequences of Unilateral Divorce for Children", University of Illinois CBA Office of Research Working Paper 000112.

Lang, K. and Zagorsky, J.L. (2001) "Does Growing Up with a Parent Absent Really Hurt?", Journal of Human Resources, 36(2): 253-273.

Manski, C., G. Sandefur, S. McLanahan and D. Powers (1992) "Alternative Estimates of the Effects of Family Structure During Adolescence on High School Graduation.” Journal of the American Statistical Association, Vol. 87, NO. 417.

Rasul, I. (2006) “The Impact of Divorce Laws on Marriage.” Unpublished manuscript.

Ruhm, C. (2004) "Parental Employment and Child Cognitive Development", Journal of Human Resources, Vol. 39, No. 1: 155-192.

Sanz de Galdeano, A. and D. Vuri (2007) 'Does Parental Divorce Affect Adolescents' Cognitive Development? Evidence from Longitudinal Data" Oxford Bulletin of Economics and Statistics, 69(3): 321-338.

Stevenson, Betsey. 2007. The impact of divorce laws on marriage-specific capital. Journal of Labor Economics, University of Chicago Press, vol. 25(1), p. 75-94.

Stevenson, Betsey. 2008. Divorce law and women's labor supply. Journal of Empirical Legal Studies, forthcoming.

Stevenson, B. and Wolfers, J. (2006) "Bargaining in the Shadow of the Law: Divorce Laws and Family Distress." Quarterly Journal of Economics, 121(1).

Tartari, M. (2005) "Divorce and the Cognitive Achievement of Children." Unpublished manuscript.

Wolfers, J. (2006) "Did Universal Divorce Laws Raise Divorce Rates? A Reconciliation and New Results.” American Economic Review, 96(5): 1802-1820. 
Figure 1. Divorce Rates in Ireland, Italy, Portugal and Spain,1950-2003

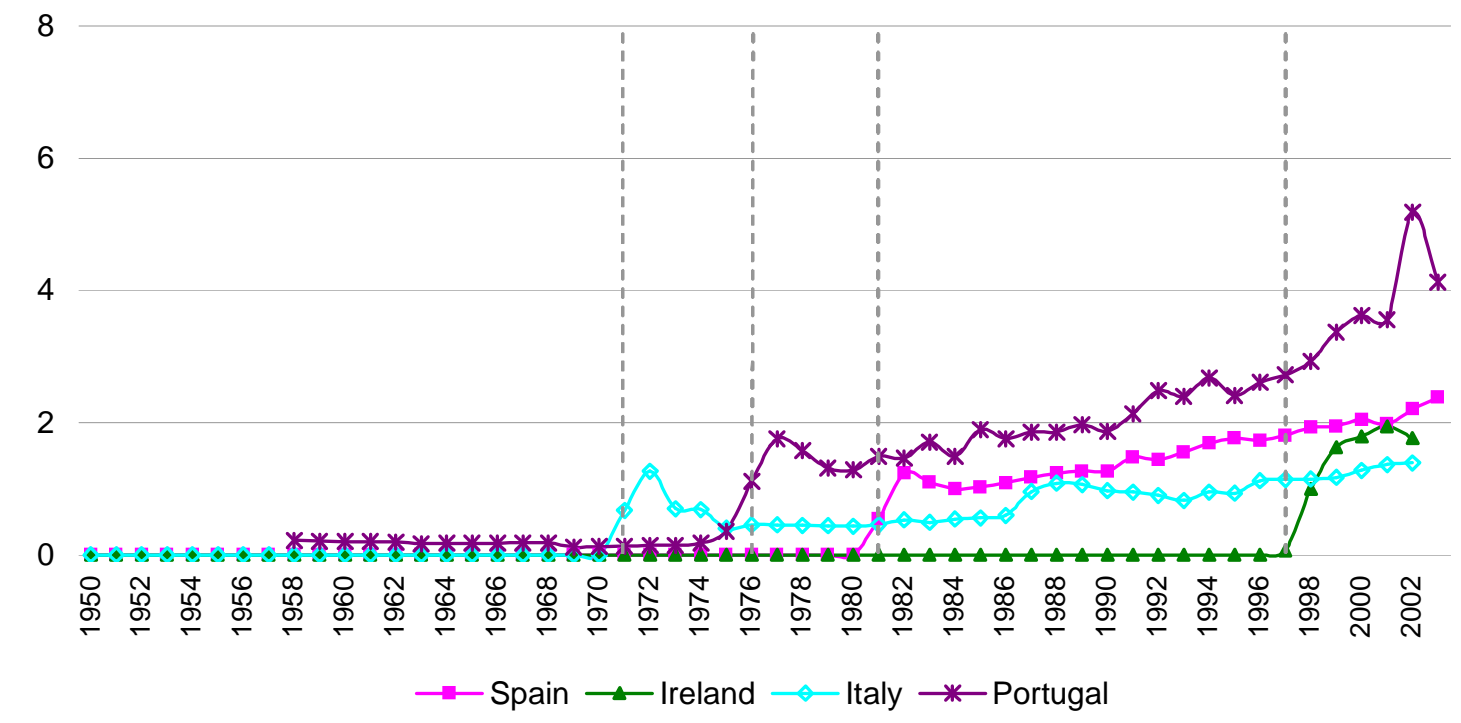

Note: Dotted vertical lines indicate the dates of legalization of divorce. Italy legalized divorce in 1971, while divorce was banned in Portugal until 1977, in Spain until 1981, and in Ireland until 1996. 


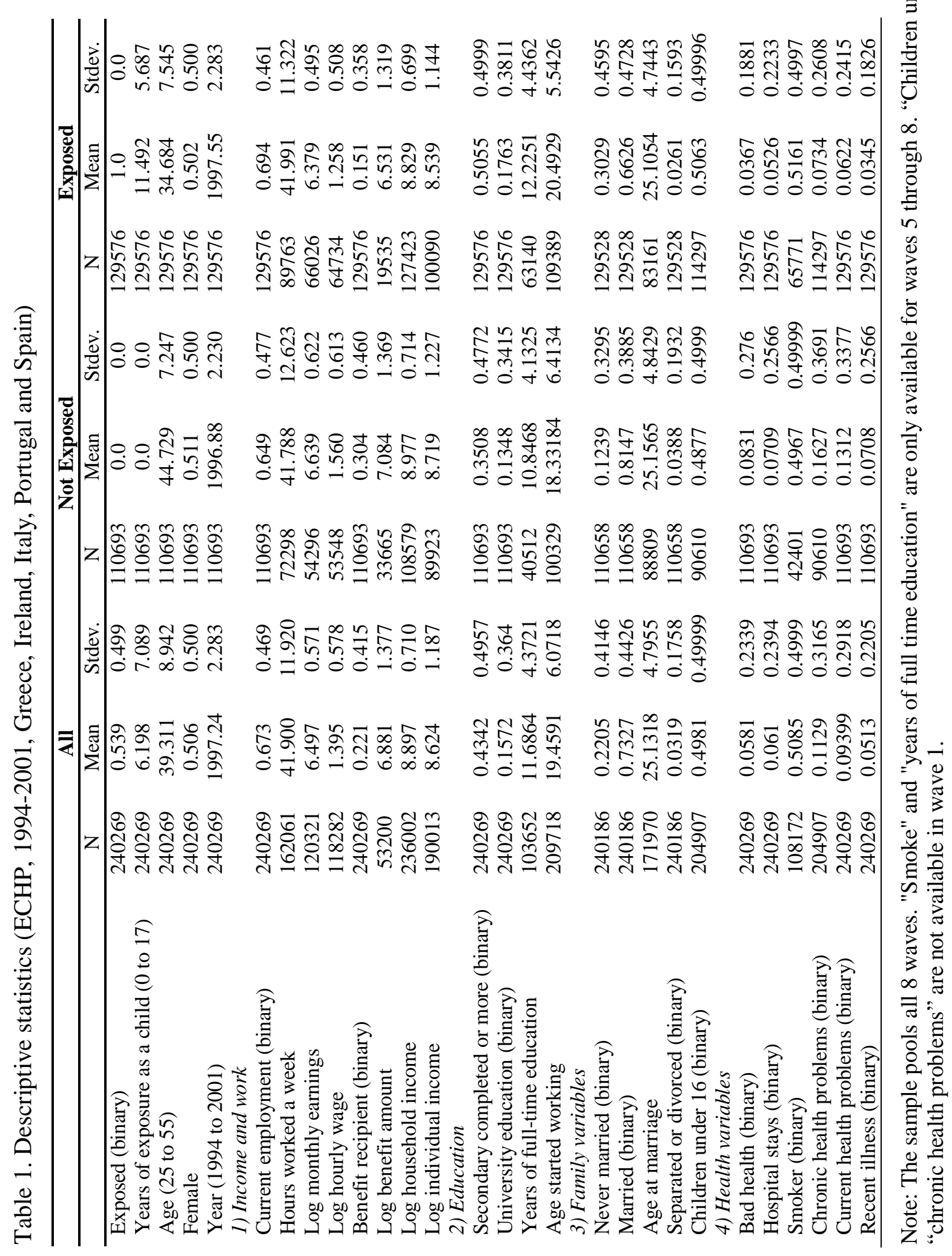


Table 2. Income and work results (ECHP, 1994-2001, Greece, Ireland, Italy, Portugal and Spain)

\begin{tabular}{|c|c|c|c|c|c|c|}
\hline \multirow{2}{*}{$\begin{array}{l}\text { Men } \\
\text { 1. Current employment (binary) }\end{array}$} & \multicolumn{2}{|l|}{$\mathbf{1}$} & 2 & \multicolumn{3}{|c|}{3} \\
\hline & 0.02 & ** & 0.019 & $*$ & 0.044 & *** \\
\hline & $(0.010)$ & & $(0.010)$ & & $(0.012)$ & \\
\hline \multirow[t]{2}{*}{ 2. Hours worked a week } & 0.451 & $* *$ & 0.515 & $* * *$ & 0.632 & $* * *$ \\
\hline & $(0.185)$ & & $(0.185)$ & & $(0.211)$ & \\
\hline \multirow[t]{2}{*}{ 3. Log monthly earnings } & 0.026 & $* *$ & 0.027 & $* *$ & -0.002 & \\
\hline & $(0.013)$ & & $(0.012)$ & & $(0.013)$ & \\
\hline \multirow[t]{2}{*}{ 4. Log hourly wage } & 0.022 & & 0.021 & & -0.017 & \\
\hline & $(0.013)$ & & $(0.013)$ & & $(0.014)$ & \\
\hline \multirow[t]{2}{*}{ 5. Benefit recipient (binary) } & -0.057 & $* * *$ & -0.056 & $* * *$ & -0.026 & \\
\hline & $(0.016)$ & & $(0.017)$ & & $(0.022)$ & \\
\hline \multirow[t]{2}{*}{ 6. Log benefit amount } & -0.039 & & -0.044 & & -0.041 & \\
\hline & $(0.054)$ & & $(0.054)$ & & $(0.062)$ & \\
\hline \multirow[t]{2}{*}{ 7. Log individual income (net) } & -0.051 & $* *$ & -0.052 & $* *$ & -0.038 & \\
\hline & $(0.022)$ & & $(0.021)$ & & $(0.027)$ & \\
\hline \multirow[t]{2}{*}{ 8. Log household income (net) } & -0.001 & & -0.004 & & 0.015 & \\
\hline & $(0.014)$ & & $(0.014)$ & & $(0.019)$ & \\
\hline Women & 1 & & 2 & & 3 & \\
\hline \multirow[t]{2}{*}{ 1. Current employment (binary) } & 0.002 & & 0.003 & & 0.025 & \\
\hline & $(0.014)$ & & $(0.014)$ & & $(0.016)$ & \\
\hline \multirow[t]{2}{*}{ 2. Hours worked a week } & -0.934 & $* * *$ & -0.934 & $* * *$ & -0.397 & \\
\hline & $(0.345)$ & & $(0.350)$ & & $(0.405)$ & \\
\hline \multirow[t]{2}{*}{ 3. Log monthly earnings } & -0.111 & $* * *$ & -0.108 & $* * *$ & -0.047 & $* *$ \\
\hline & $(0.026)$ & & $(0.025)$ & & $(0.022)$ & \\
\hline \multirow[t]{2}{*}{ 4. Log hourly wage } & -0.047 & $* *$ & -0.046 & $* *$ & -0.027 & \\
\hline & $(0.020)$ & & $(0.020)$ & & $(0.022)$ & \\
\hline \multirow[t]{2}{*}{ 5. Benefit recipient (binary) } & 0.019 & & 0.018 & & 0.01 & \\
\hline & $(0.012)$ & & $(0.012)$ & & $(0.012)$ & \\
\hline \multirow[t]{2}{*}{ 6. Log benefit amount } & -0.538 & $* * *$ & -0.518 & $* * *$ & -0.106 & $*$ \\
\hline & $(0.073)$ & & $(0.073)$ & & $(0.056)$ & \\
\hline \multirow[t]{2}{*}{ 7. Log individual income (net) } & -0.286 & $* * *$ & -0.269 & $* * *$ & -0.069 & \\
\hline & $(0.053)$ & & $(0.050)$ & & $(0.045)$ & \\
\hline \multirow[t]{2}{*}{ 8. Log household income (net) } & -0.006 & & -0.009 & & -0.004 & \\
\hline & $(0.015)$ & & $(0.015)$ & & $(0.019)$ & \\
\hline Country fixed effects? & $\mathrm{Y}$ & & $\mathrm{Y}$ & & $\mathrm{Y}$ & \\
\hline Country-specific trends? & $\mathrm{N}$ & & $\mathrm{Y}$ & & $\mathrm{N}$ & \\
\hline Country-specific trends y.birth? & $\mathrm{N}$ & & $\mathrm{N}$ & & $\mathrm{Y}$ & \\
\hline
\end{tabular}

Note: Each row reports the results for a different dependent variable and 3 different specifications. The coefficients shown are for "exposure to legal divorce during childhood" (binary). All specifications are linear. One asterisk indicates significance at the $90 \%$ confidence level, two indicate $95 \%$ and three, $99 \%$. 
Table 3. Income and Work Results by Exposure (ECHP, 1994-2001, Greece, Ireland, Italy, Portugal and Spain)

\begin{tabular}{|c|c|c|c|c|c|c|}
\hline Men & 1 to 4 years & & 5 to 8 years & & 9 or + years & \\
\hline $\begin{array}{l}\text { 1. Current employment } \\
\text { (binary) }\end{array}$ & $\begin{array}{c}0.042 \\
(0.013)\end{array}$ & $* * *$ & $\begin{array}{c}0.052 \\
(0.015)\end{array}$ & $* * *$ & $\begin{array}{c}0.057 \\
(0.021)\end{array}$ & $* * *$ \\
\hline 2. Hours worked a week & $\begin{array}{c}0.629 \\
(0.230)\end{array}$ & $* * *$ & $\begin{array}{c}0.748 \\
(0.252)\end{array}$ & $* * *$ & $\begin{array}{c}0.868 \\
(0.385)\end{array}$ & $* *$ \\
\hline 3. Log monthly earnings & $\begin{array}{l}-0.002 \\
(0.013)\end{array}$ & & $\begin{array}{c}0.019 \\
(0.016)\end{array}$ & & $\begin{array}{c}0.043 \\
(0.021)\end{array}$ & $* *$ \\
\hline 4. Log hourly wage & $\begin{array}{l}-0.019 \\
(0.015)\end{array}$ & & $\begin{array}{c}0.007 \\
(0.017)\end{array}$ & & $\begin{array}{c}0.028 \\
(0.023)\end{array}$ & \\
\hline 5. Benefit recipient (binary) & $\begin{array}{l}-0.035 \\
(0.023)\end{array}$ & & $\begin{array}{l}-0.065 \\
(0.026)\end{array}$ & $* *$ & $\begin{array}{l}-0.154 \\
(0.039)\end{array}$ & $* * *$ \\
\hline 6. Log benefit amount & $\begin{array}{c}0 \\
(0.065)\end{array}$ & & $\begin{array}{l}-0.023 \\
(0.069)\end{array}$ & & $\begin{array}{c}0.176 \\
(0.098)\end{array}$ & $*$ \\
\hline 7. Log individual income (net) & $\begin{array}{l}-0.031 \\
(0.031)\end{array}$ & & $\begin{array}{l}-0.061 \\
(0.032)\end{array}$ & $*$ & $\begin{array}{l}-0.063 \\
(0.056)\end{array}$ & \\
\hline 8. Log household income (net) & $\begin{array}{c}0.01 \\
(0.020)\end{array}$ & & $\begin{array}{c}0.04 \\
(0.021)\end{array}$ & $*$ & $\begin{array}{c}0.051 \\
(0.028)\end{array}$ & $*$ \\
\hline \multicolumn{7}{|l|}{ Women } \\
\hline $\begin{array}{l}\text { 1. Current employment } \\
\text { (binary) }\end{array}$ & $\begin{array}{c}0.015 \\
(0.018)\end{array}$ & & $\begin{array}{c}0.047 \\
(0.015)\end{array}$ & $* * *$ & $\begin{array}{c}0.035 \\
(0.022)\end{array}$ & \\
\hline 2. Hours worked a week & $\begin{array}{l}-0.526 \\
(0.430)\end{array}$ & & $\begin{array}{l}-0.191 \\
(0.465)\end{array}$ & & $\begin{array}{l}-0.464 \\
(0.671)\end{array}$ & \\
\hline 3. Log monthly earnings & $\begin{array}{l}-0.043 \\
(0.023)\end{array}$ & $*$ & $\begin{array}{l}-0.082 \\
(0.026)\end{array}$ & $* * *$ & $\begin{array}{l}-0.099 \\
(0.032)\end{array}$ & $* * *$ \\
\hline 4. Log hourly wage & $\begin{array}{l}-0.019 \\
(0.024)\end{array}$ & & $\begin{array}{l}-0.058 \\
(0.026)\end{array}$ & $* *$ & $\begin{array}{l}-0.061 \\
(0.033)\end{array}$ & $*$ \\
\hline 5. Benefit recipient (binary) & $\begin{array}{c}0.009 \\
(0.012)\end{array}$ & & $\begin{array}{c}0.023 \\
(0.015)\end{array}$ & & $\begin{array}{c}0.038 \\
(0.020)\end{array}$ & $*$ \\
\hline 6. Log benefit amount & $\begin{array}{l}-0.088 \\
(0.056)\end{array}$ & & $\begin{array}{l}-0.092 \\
(0.078)\end{array}$ & & $\begin{array}{c}0.003 \\
(0.104)\end{array}$ & \\
\hline 7. Log individual income (net) & $\begin{array}{l}-0.082 \\
(0.049)\end{array}$ & $*$ & $\begin{array}{l}-0.129 \\
(0.058)\end{array}$ & $* *$ & $\begin{array}{l}-0.247 \\
(0.089)\end{array}$ & $* * *$ \\
\hline 8. Log household income (net) & $\begin{array}{l}-0.014 \\
(0.020) \\
\end{array}$ & & $\begin{array}{c}0.027 \\
(0.022) \\
\end{array}$ & & $\begin{array}{c}0.024 \\
(0.032) \\
\end{array}$ & \\
\hline
\end{tabular}

Note: Each row reports the results for a different dependent variable. The coefficients shown are for three dummies that measure the length of exposure to legal divorce during childhood. All specifications are linear and include country and year dummies and country-specific linear trends in year of birth. One asterisk indicates significance at the $90 \%$ confidence level, two indicate $95 \%$ and three, $99 \%$. 
Table 4. Education Results

(ECHP, 1994-2001, Greece, Ireland, Italy, Portugal and Spain)

\begin{tabular}{lcccccc}
\hline Men & $\mathbf{1}$ & & $\mathbf{2}$ & & $\mathbf{3}$ \\
\hline 1. High school plus (binary) & -0.025 & $* *$ & -0.027 & $* *$ & -0.005 & \\
& $(0.012)$ & & $(0.012)$ & & $(0.015)$ & \\
2. University degree (binary) & 0.008 & & 0.005 & 0.019 & \\
& $(0.010)$ & & $(0.011)$ & & $(0.012)$ & \\
3. Years of full time & & & & & & \\
education & 0.365 & $* *$ & 0.362 & $* *$ & 0.454 & $* *$ \\
& $(0.143)$ & & $(0.144)$ & & $(0.160)$ & \\
4. Age when started working & 0.416 & $* *$ & 0.383 & $* *$ & 0.472 & $* *$ \\
& $(0.167)$ & & $(0.168)$ & & $(0.187)$ & \\
\hline Women & $\mathbf{1}$ & & $\mathbf{2}$ & & $\mathbf{3}$ & \\
\hline 1. High school plus (binary) & 0 & & -0.003 & & 0.008 & \\
& $(0.013)$ & & $(0.014)$ & & $(0.017)$ & \\
2. University degree (binary) & -0.004 & & -0.011 & & 0.013 & \\
& $(0.012)$ & & $(0.012)$ & & $(0.013)$ & \\
3. Years of full time & & & & & & \\
education & 0.403 & $* * *$ & 0.399 & $* * *$ & 0.322 & $* *$ \\
& $(0.128)$ & & $(0.128)$ & & $(0.160)$ & \\
4. Age when started working & 0.379 & $*$ & 0.352 & $*$ & 0.42 & $* *$ \\
& $(0.209)$ & & $(0.211)$ & & $(0.191)$ & \\
\hline Country fixed effects? & $\mathrm{Y}$ & & $\mathrm{Y}$ & & $\mathrm{Y}$ & \\
Country-specific trends? & $\mathrm{N}$ & & $\mathrm{Y}$ & & $\mathrm{N}$ & \\
Country-specific trends in & & & & & $\mathrm{Y}$ & \\
year of birth? & $\mathrm{N}$ & & $\mathrm{N}$ & & & \\
\hline
\end{tabular}

Note: Each row reports the results for a different dependent variable and 3 different specifications. The coefficients shown are for "exposure to legal divorce during childhood" (binary). All specifications are linear. One asterisk indicates significance at the $90 \%$ confidence level, two indicate $95 \%$ and three, $99 \%$. 
Table 5. Education Results, by Exposure

(ECHP, 1994-2001, Greece, Ireland, Italy, Portugal and Spain)

\begin{tabular}{|c|c|c|c|c|c|c|}
\hline Men & $\begin{array}{l}1 \text { to } 4 \\
\text { years }\end{array}$ & & $\begin{array}{l}5 \text { to } 8 \\
\text { years }\end{array}$ & & $\begin{array}{l}9 \text { or }+ \\
\text { years }\end{array}$ & \\
\hline \multirow[t]{2}{*}{ 1. High school plus (binary) } & -0.01 & & -0.005 & & -0.028 & \\
\hline & $(0.016)$ & & $(0.016)$ & & $(0.023)$ & \\
\hline \multirow[t]{2}{*}{ 2. University degree (binary) } & 0.016 & & 0.042 & $* * *$ & 0.061 & $* * *$ \\
\hline & $(0.013)$ & & $(0.014)$ & & $(0.019)$ & \\
\hline \multirow[t]{2}{*}{$\begin{array}{l}\text { 3. Years of full time } \\
\text { education }\end{array}$} & 0.451 & $* *$ & 0.713 & $* * *$ & 1.013 & $* * *$ \\
\hline & $(0.200)$ & & $(0.204)$ & & $(0.266)$ & \\
\hline \multirow[t]{2}{*}{ 3. Age when started working } & 0.527 & $* * *$ & 0.343 & & 0.401 & \\
\hline & $(0.201)$ & & $(0.238)$ & & $(0.365)$ & \\
\hline \multicolumn{7}{|l|}{ Women } \\
\hline \multirow[t]{2}{*}{ 1. High school plus (binary) } & 0.008 & & 0.01 & & 0.017 & \\
\hline & $(0.019)$ & & $(0.018)$ & & $(0.023)$ & \\
\hline \multirow[t]{2}{*}{ 2. University degree (binary) } & 0.017 & & 0.014 & & 0.031 & \\
\hline & $(0.014)$ & & $(0.015)$ & & $(0.020)$ & \\
\hline \multirow[t]{2}{*}{$\begin{array}{l}\text { 3. Years of full time } \\
\text { education }\end{array}$} & 0.335 & $* *$ & 0.52 & $* *$ & 0.799 & $* * *$ \\
\hline & $(0.160)$ & & $(0.205)$ & & $(0.253)$ & \\
\hline \multirow[t]{2}{*}{ 4. Age when started working } & 0.472 & $* *$ & 0.183 & & 0.124 & \\
\hline & $(0.190)$ & & $(0.248)$ & & $(0.276)$ & \\
\hline
\end{tabular}

Note: Each row reports the results for a different dependent variable. The coefficients shown are for three dummies that measure the length of exposure to legal divorce during childhood. All specifications are linear and include country and year dummies and country-specific linear trends in year of birth. One asterisk indicates significance at the $90 \%$ confidence level, two indicate $95 \%$ and three, $99 \%$. 
Table 6. Family Results

(ECHP, 1994-2001, Greece, Ireland, Italy, Portugal and Spain)

\begin{tabular}{|c|c|c|c|c|c|c|}
\hline Men & 1 & & 2 & & 3 & \\
\hline \multirow[t]{2}{*}{ 1. Never married (binary) } & -0.011 & & -0.009 & & -0.004 & \\
\hline & $(0.011)$ & & $(0.010)$ & & $(0.012)$ & \\
\hline \multirow[t]{2}{*}{ 2. Married (binary) } & 0.013 & & 0.012 & & 0.004 & \\
\hline & $(0.011)$ & & $(0.011)$ & & $(0.012)$ & \\
\hline \multirow[t]{2}{*}{ 3. Age at marriage } & 0.790 & $* * *$ & 0.762 & $* * *$ & 0.734 & $* * *$ \\
\hline & $(0.182)$ & & $(0.184)$ & & $(0.232)$ & \\
\hline \multirow{2}{*}{$\begin{array}{l}\text { 4. Separated or divorced } \\
\text { (binary) }\end{array}$} & רח00 & & 0003 & & P00? & \\
\hline & $\begin{array}{l}-0.002 \\
(0.004)\end{array}$ & & $\begin{array}{l}-0.003 \\
(0.004)\end{array}$ & & $\begin{array}{l}-0.002 \\
(0.005)\end{array}$ & \\
\hline \multirow{2}{*}{ 5. Children under 16 (binary) } & 0.03 & $*$ & 0.031 & $* *$ & 0.006 & \\
\hline & $(0.015)$ & & $(0.015)$ & & $(0.017)$ & \\
\hline Women & 1 & & 2 & & & \\
\hline \multirow[t]{2}{*}{ 1. Never married (binary) } & 0.005 & & 0.006 & & -0.007 & \\
\hline & $(0.011)$ & & $(0.011)$ & & $(0.012)$ & \\
\hline \multirow[t]{2}{*}{ 2. Married (binary) } & -0.006 & & -0.006 & & 0.007 & \\
\hline & $(0.013)$ & & $(0.013)$ & & $(0.013)$ & \\
\hline \multirow[t]{2}{*}{ 3. Age at marriage } & 0.306 & $*$ & 0.268 & & -0.016 & \\
\hline & $(0.181)$ & & $(0.182)$ & & $(0.215)$ & \\
\hline \multirow{3}{*}{$\begin{array}{l}\text { 4. Separated or divorced } \\
\text { (binary) }\end{array}$} & & & & & & \\
\hline & 0.001 & & 0.001 & & $\begin{array}{c}0 \\
0007)\end{array}$ & \\
\hline & $(0.005)$ & & $(0.005)$ & & $(0.007)$ & \\
\hline \multirow[t]{2}{*}{ 5. Children under 16 (binary) } & -0.01 & & -0.008 & & 0.021 & \\
\hline & $(0.018)$ & & $(0.018)$ & & $(0.020)$ & \\
\hline Country fixed effects? & $\mathrm{Y}$ & & $\mathrm{Y}$ & & $\mathrm{Y}$ & \\
\hline Country-specific trends? & $\mathrm{N}$ & & $\mathrm{Y}$ & & $\mathrm{N}$ & \\
\hline $\begin{array}{l}\text { Country-specific trends } \\
\text { y.birth? }\end{array}$ & $\mathrm{N}$ & & $\mathrm{N}$ & & Y & \\
\hline
\end{tabular}

Note: Each row reports the results for a different dependent variable and 3 different specifications. The coefficients shown are for "exposure to legal divorce during childhood" (binary). All specifications are linear. One asterisk indicates significance at the $90 \%$ confidence level, two indicate $95 \%$ and three, $99 \%$. 
Table 7. Family Results, by Exposure (ECHP, 1994-2001, Greece, Ireland, Italy, Portugal and Spain)

\begin{tabular}{|c|c|c|c|c|c|c|}
\hline Men & $\begin{array}{l}1 \text { to } 4 \\
\text { years }\end{array}$ & & $\begin{array}{l}5 \text { to } 8 \\
\text { years }\end{array}$ & & $\begin{array}{l}9 \text { or }+ \\
\text { years }\end{array}$ & \\
\hline \multirow[t]{2}{*}{ 1. Never married (binary) } & 0.002 & & -0.018 & & -0.014 & \\
\hline & $(0.014)$ & & $(0.015)$ & & $(0.028)$ & \\
\hline \multirow[t]{2}{*}{ 2. Married (binary) } & -0.001 & & 0.023 & & 0.029 & \\
\hline & $(0.014)$ & & $(0.014)$ & & $(0.026)$ & \\
\hline \multirow[t]{2}{*}{ 3. Age at marriage } & 0.63 & $* * *$ & 1.592 & $* * *$ & 2.013 & $* * *$ \\
\hline & $(0.211)$ & & $(0.196)$ & & $(0.321)$ & \\
\hline \multirow[t]{2}{*}{$\begin{array}{l}\text { 4. Separated or divorced } \\
\text { (binary) }\end{array}$} & -0.003 & & -0.008 & & -0.02 & $* *$ \\
\hline & $(0.006)$ & & $(0.006)$ & & $(0.008)$ & \\
\hline \multirow[t]{2}{*}{ 5. Children under 16} & 0.006 & & -0.011 & & -0.033 & \\
\hline & $(0.017)$ & & $(0.022)$ & & $(0.026)$ & \\
\hline \multicolumn{7}{|l|}{ Women } \\
\hline \multirow[t]{2}{*}{ 1. Never married (binary) } & -0.012 & & 0.007 & & 0.004 & \\
\hline & $(0.013)$ & & $(0.016)$ & & $(0.025)$ & \\
\hline \multirow[t]{2}{*}{ 2. Married (binary) } & 0.015 & & -0.006 & & 0.01 & \\
\hline & $(0.013)$ & & $(0.017)$ & & $(0.025)$ & \\
\hline \multirow[t]{2}{*}{ 3. Age at marriage } & 0.015 & & 0.72 & $* * *$ & 1.599 & $* * *$ \\
\hline & $(0.184)$ & & $(0.229)$ & & $(0.316)$ & \\
\hline \multirow{2}{*}{$\begin{array}{l}\text { 4. Separated or divorced } \\
\text { (binary) }\end{array}$} & & & & & & \\
\hline & $\begin{array}{l}-0.002 \\
(0.007)\end{array}$ & & $\begin{array}{c}-0.001 \\
(0.008)\end{array}$ & & $\begin{array}{c}-0.01 \\
(0.010)\end{array}$ & \\
\hline \multirow[t]{2}{*}{ 5. Children under 16} & 0.024 & & -0.005 & & -0.021 & \\
\hline & $(0.020)$ & & $(0.027)$ & & $(0.034)$ & \\
\hline
\end{tabular}

Note: Each row reports the results for a different dependent variable. The coefficients shown are for three dummies that measure the length of exposure to legal divorce during childhood. All specifications are linear and include country and year dummies and country-specific linear trends in year of birth. One asterisk indicates significance at the $90 \%$ confidence level, two indicate $95 \%$ and three, $99 \%$. 
Table 8. Health Results (ECHP, 1994-2001, Greece, Ireland, Italy, Portugal and Spain)

\begin{tabular}{|c|c|c|c|c|c|c|}
\hline Men & 1 & & 2 & & 3 & \\
\hline $\begin{array}{l}\text { 1. Self-reported bad health } \\
\text { (binary) }\end{array}$ & $\begin{array}{l}-0.019 \\
(0.004)\end{array}$ & $* * *$ & $\begin{array}{l}-0.018 \\
(0.004)\end{array}$ & $* * *$ & $\begin{array}{c}0.004 \\
(0.005)\end{array}$ & \\
\hline 2. Hospital stays (binary) & $\begin{array}{l}-0.007 \\
(0.003)\end{array}$ & $* *$ & $\begin{array}{l}-0.007 \\
(0.003)\end{array}$ & $* *$ & $\begin{array}{c}0 \\
(0.004)\end{array}$ & \\
\hline 3. Ever a smoker (binary) & $\begin{array}{l}-0.049 \\
(0.013)\end{array}$ & $* * *$ & $\begin{array}{l}-0.049 \\
(0.013)\end{array}$ & $* * *$ & $\begin{array}{l}-0.049 \\
(0.018)\end{array}$ & $* * *$ \\
\hline 4. Chronic illness (binary) & $\begin{array}{l}-0.007 \\
(0.006)\end{array}$ & & $\begin{array}{l}-0.006 \\
(0.006)\end{array}$ & & $\begin{array}{c}0.002 \\
(0.008)\end{array}$ & \\
\hline $\begin{array}{l}\text { 5. Current health problem } \\
\text { (binary) }\end{array}$ & $\begin{array}{l}-0.007 \\
(0.005)\end{array}$ & & $\begin{array}{l}-0.006 \\
(0.005)\end{array}$ & & $\begin{array}{c}0 \\
(0.007)\end{array}$ & \\
\hline 6. Recent illness (binary) & $\begin{array}{c}0 \\
(0.003) \\
\end{array}$ & & $\begin{array}{c}0 \\
(0.003) \\
\end{array}$ & & $\begin{array}{c}0.006 \\
(0.004) \\
\end{array}$ & \\
\hline Women & 1 & & 2 & & 3 & \\
\hline $\begin{array}{l}\text { 1. Self-reported bad health } \\
\text { (binary) }\end{array}$ & $\begin{array}{l}-0.033 \\
(0.006)\end{array}$ & $* * *$ & $\begin{array}{l}-0.032 \\
(0.006)\end{array}$ & $* * *$ & $\begin{array}{c}0.007 \\
(0.005)\end{array}$ & \\
\hline 2. Hospital stays (binary) & $\begin{array}{c}0.007 \\
(0.003)\end{array}$ & $* *$ & $\begin{array}{c}0.006 \\
(0.003)\end{array}$ & $* *$ & $\begin{array}{c}0.003 \\
(0.004)\end{array}$ & \\
\hline 3. Ever a smoker (binary) & $\begin{array}{c}0.023 \\
(0.018)\end{array}$ & & $\begin{array}{c}0.024 \\
(0.018)\end{array}$ & & $\begin{array}{l}-0.013 \\
(0.021)\end{array}$ & \\
\hline 4. Chronic illness (binary) & $\begin{array}{l}-0.015 \\
(0.007)\end{array}$ & $* *$ & $\begin{array}{l}-0.015 \\
(0.007)\end{array}$ & $* *$ & $\begin{array}{l}0.008 \\
(0.007)\end{array}$ & \\
\hline $\begin{array}{l}\text { 5. Current health problem } \\
\text { (binary) }\end{array}$ & $\begin{array}{c}-0.018 \\
(0.006)\end{array}$ & $* * *$ & $\begin{array}{l}-0.016 \\
(0.006)\end{array}$ & $* * *$ & $\begin{array}{c}0.007 \\
(0.006)\end{array}$ & \\
\hline 6. Recent illness (binary) & $\begin{array}{c}.007 \\
(0.004) \\
\end{array}$ & $*$ & $\begin{array}{r}-0.008 \\
(0.004) \\
\end{array}$ & $* *$ & $\begin{array}{c}0.006 \\
(0.004)\end{array}$ & \\
\hline Country fixed effects? & $\mathrm{Y}$ & & $\mathrm{Y}$ & & $\mathrm{Y}$ & \\
\hline Country-specific trends? & $\mathrm{N}$ & & $\mathrm{Y}$ & & $\mathrm{N}$ & \\
\hline Country-specific trends y.birth? & $\mathrm{N}$ & & $\mathrm{N}$ & & $\mathrm{Y}$ & \\
\hline
\end{tabular}

Note: Each row reports the results for a different dependent variable and 3 different specifications. The coefficients shown are for "exposure to legal divorce during childhood" (binary). All specifications are linear. One asterisk indicates significance at the $90 \%$ confidence level, two indicate $95 \%$ and three, $99 \%$. 
Table 9. Health Results by Exposure (ECHP, 1994-2001, Greece, Ireland, Italy, Portugal and Spain)

\begin{tabular}{|c|c|c|c|c|c|c|}
\hline Men & $\begin{array}{l}1 \text { to } 4 \\
\text { years }\end{array}$ & & $\begin{array}{l}5 \text { to } 8 \\
\text { years }\end{array}$ & & $\begin{array}{l}9 \text { or }+ \\
\text { years }\end{array}$ & \\
\hline $\begin{array}{l}\text { 1. Self-reported bad health } \\
\text { (binary) }\end{array}$ & $\begin{array}{c}0.003 \\
(0.005)\end{array}$ & & $\begin{array}{c}0.005 \\
(0.006)\end{array}$ & & $\begin{array}{c}0.003 \\
(0.008)\end{array}$ & \\
\hline 2. Hospital stays (binary) & $\begin{array}{c}0 \\
(0.004)\end{array}$ & & $\begin{array}{l}-0.004 \\
(0.004)\end{array}$ & & $\begin{array}{l}-0.011 \\
(0.006)\end{array}$ & $*$ \\
\hline 3. Ever a smoker (binary) & $\begin{array}{l}-0.038 \\
(0.019)\end{array}$ & $* *$ & $\begin{array}{l}-0.097 \\
(0.016)\end{array}$ & $* * *$ & $\begin{array}{l}-0.116 \\
(0.024)\end{array}$ & $* * *$ \\
\hline 4. Chronic illness (binary) & $\begin{array}{c}0.003 \\
(0.009)\end{array}$ & & $\begin{array}{c}0.001 \\
(0.009)\end{array}$ & & $\begin{array}{c}0.001 \\
(0.012)\end{array}$ & \\
\hline $\begin{array}{l}\text { 5. Current health problem } \\
\text { (binary) }\end{array}$ & $\begin{array}{c}0.001 \\
(0.007)\end{array}$ & & $\begin{array}{l}-0.004 \\
(0.007)\end{array}$ & & $\begin{array}{c}0.002 \\
(0.010)\end{array}$ & \\
\hline 6. Recent illness (binary) & $\begin{array}{c}0.008 \\
(0.004) \\
\end{array}$ & $* *$ & $\begin{array}{l}-0.002 \\
(0.004)\end{array}$ & & $\begin{array}{l}-0.001 \\
(0.005)\end{array}$ & \\
\hline \multicolumn{7}{|l|}{ Women } \\
\hline $\begin{array}{l}\text { 1. Self-reported bad health } \\
\text { (binary) }\end{array}$ & $\begin{array}{c}0.01 \\
(0.006)\end{array}$ & & $\begin{array}{c}0.016 \\
(0.006)\end{array}$ & & $\begin{array}{c}0.038 \\
(0.009)\end{array}$ & \\
\hline 2. Hospital stays (binary) & $\begin{array}{c}0.005 \\
(0.004)\end{array}$ & & $\begin{array}{c}0.008 \\
(0.004)\end{array}$ & $*$ & $\begin{array}{c}0.021 \\
(0.007)\end{array}$ & $* * *$ \\
\hline 3. Ever a smoker (binary) & $\begin{array}{l}-0.027 \\
(0.022)\end{array}$ & & $\begin{array}{l}-0.018 \\
(0.027)\end{array}$ & & $\begin{array}{l}-0.084 \\
(0.037)\end{array}$ & $* *$ \\
\hline 4. Chronic illness (binary) & $\begin{array}{c}0.012 \\
(0.008)\end{array}$ & & $\begin{array}{c}0.015 \\
(0.008)\end{array}$ & $*$ & $\begin{array}{c}0.041 \\
(0.012)\end{array}$ & $* * *$ \\
\hline $\begin{array}{l}\text { 5. Current health problem } \\
\text { (binary) }\end{array}$ & $\begin{array}{c}0.01 \\
(0.006)\end{array}$ & & $\begin{array}{c}0.02 \\
(0.007)\end{array}$ & $* * *$ & $\begin{array}{c}0.049 \\
(0.011)\end{array}$ & $* * *$ \\
\hline 6. Recent illness (binary) & $\begin{array}{c}0.006 \\
(0.004)\end{array}$ & $*$ & $\begin{array}{c}0.013 \\
(0.004)\end{array}$ & $* * *$ & $\begin{array}{c}0.021 \\
(0.007)\end{array}$ & $* * *$ \\
\hline
\end{tabular}

Note: Each row reports the results for a different dependent variable. The coefficients shown are for three dummies that measure the length of exposure to legal divorce during childhood. All specifications are linear and include country and year dummies and country-specific linear trends in year of birth. One asterisk indicates significance at the $90 \%$ confidence level; two indicate $95 \%$ and three, $99 \%$. 


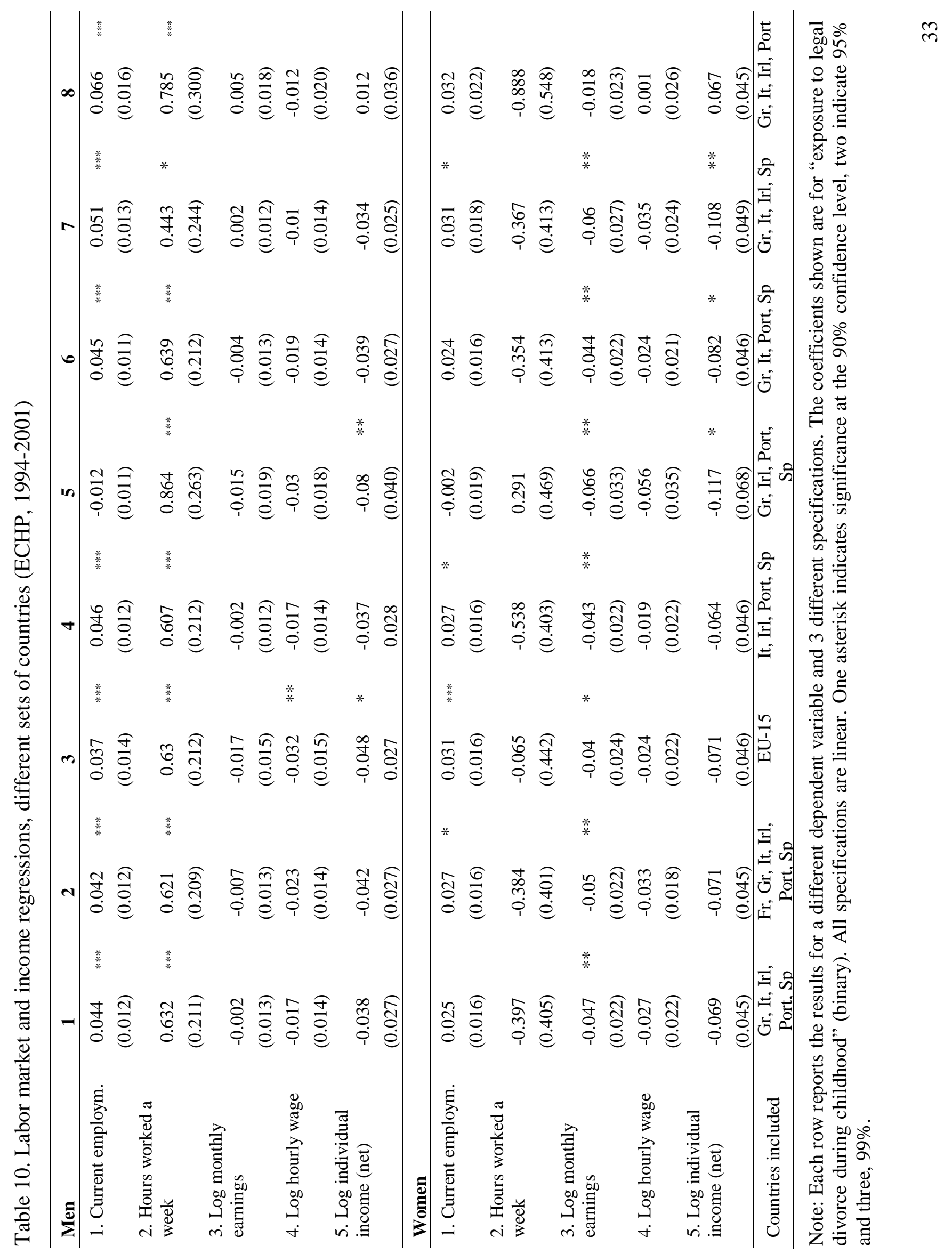




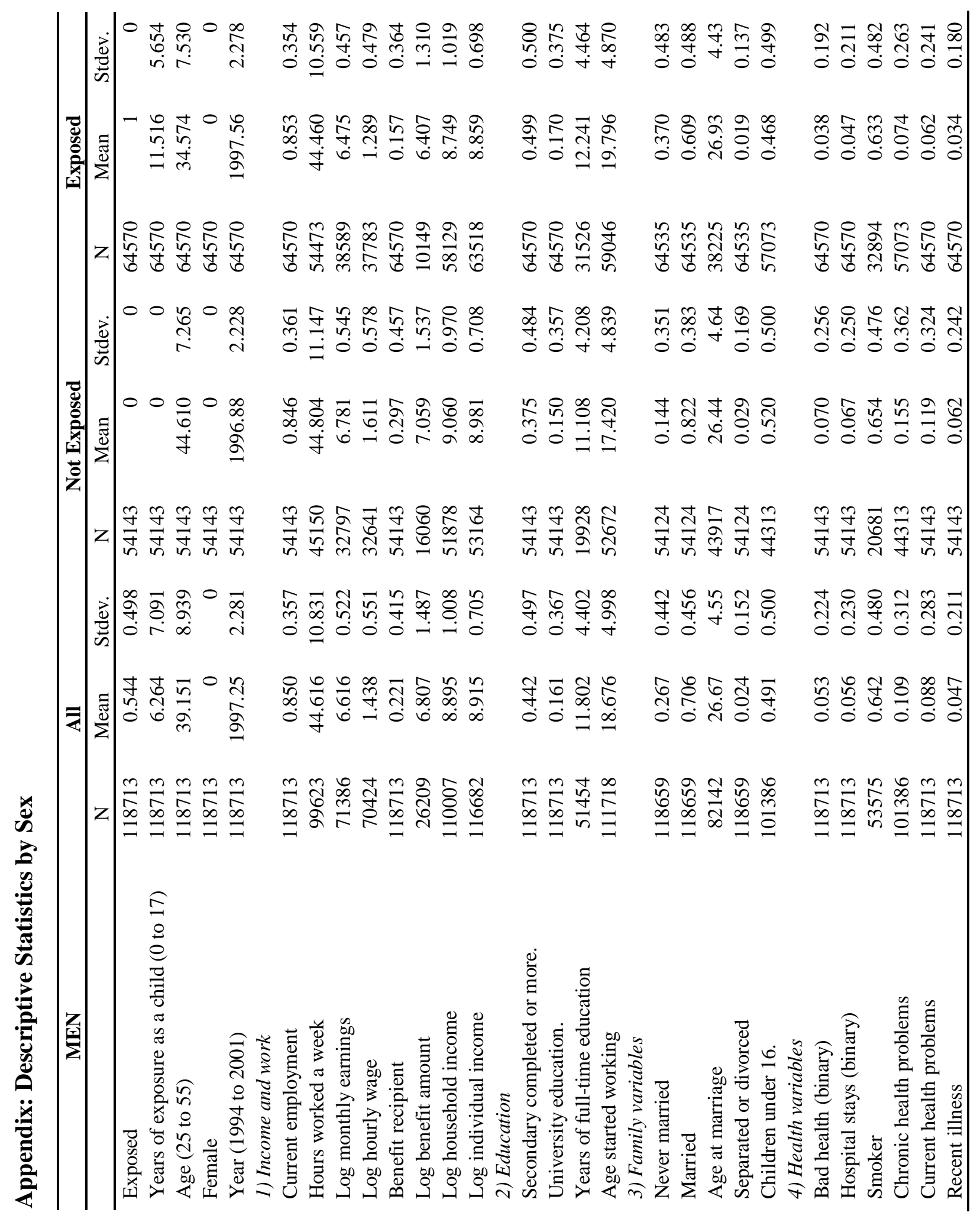




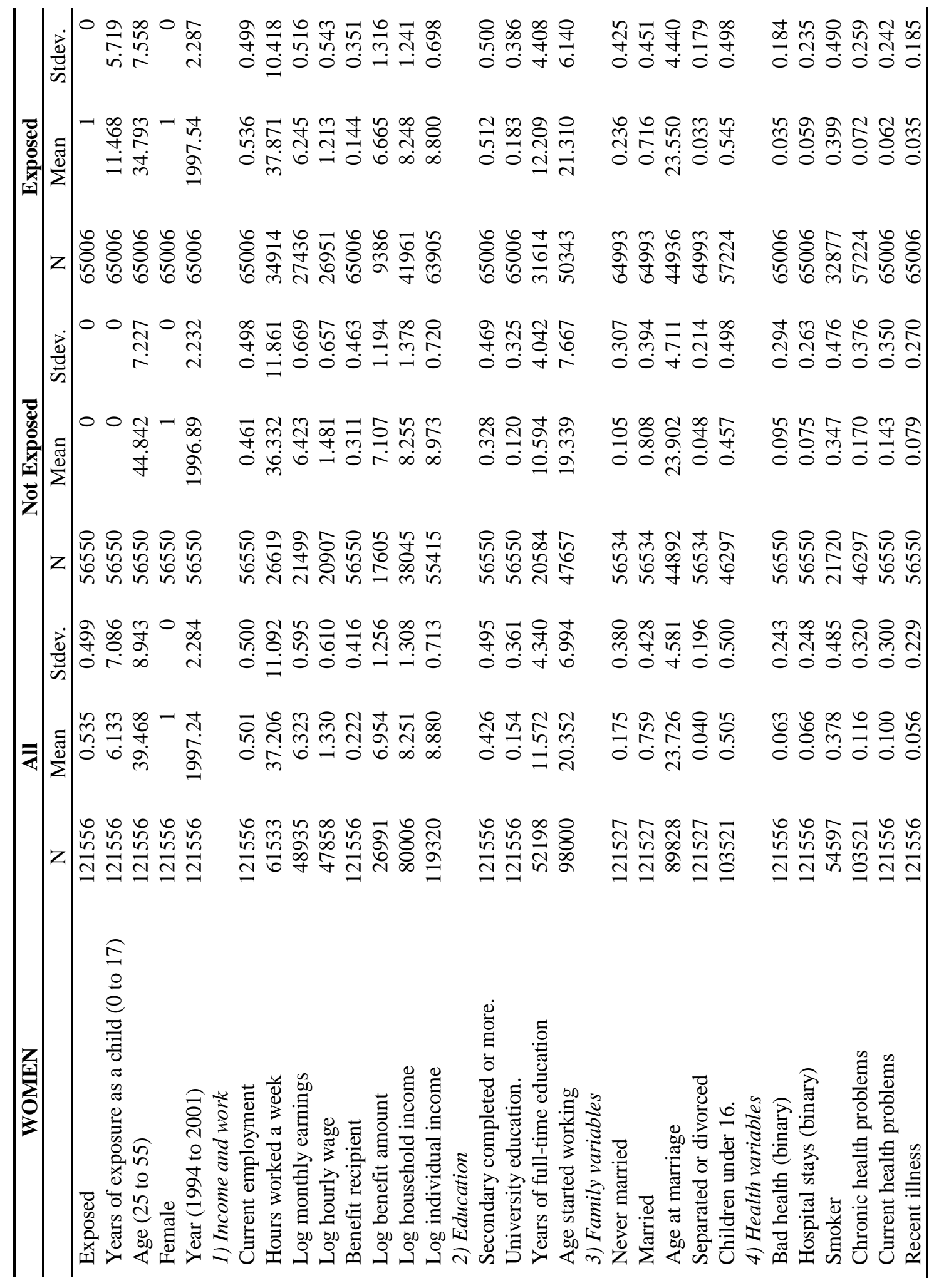

